Jurnal Akuakultur Sungai dan Danau Vol. 2 No. 1 Tahun 2017 Hal. 1 - 8

ISSN Online 2503-4766

\title{
PEMANFAATAN SALURAN IRIGASI UNTUK BUDIDAYA IKAN LELE SANGKURIANG (Clarias gariepinus Var Sangkuriang) DENGAN SISTEM RESIRKULASI DI DESA PUDAK KECAMATAN MUARO KUMPEH KABUPATEN MUARO JAMBI PROVINSI JAMBI
}

\author{
Muarofah Ghofur \\ Program Studi Budidaya Perairan, Fakultas Pertanian Universitas Batanghari \\ Jl. Slamet Riyadi, Broni Jambi. 36122. Telp. +62074160103 \\ Email : muarofah_ghofur@yahoo.com
}

\begin{abstract}
Irrigation systemis majority use for agricultural activies but actually the case is also can be use for fish farming. One variety of this potential fish farming is "lele sangkuriang" (Clarias gariepinus Var Sangkuriang). "Lele Sangkuriang" is a freshwater fish which pleasurely lives in rapids water. The ideal condition to live for this variety is $\mathrm{pH}$ 6,5-9 of acidity and $24^{\circ} \mathrm{C}-26^{\circ} \mathrm{C}$. The excess of $\mathrm{O}^{2}$ contain will causevesicle fenomena in it body tissue and sudden deceasing of $\mathrm{O}^{2}$ on the contrary, will cause death. Recirculation system is one of the way to improve the water quality.support $O^{2}$ distriution all around and accumulation maintaining or collecting the poison metabolic product so that it can reduce the media poison concentration. These are suh the bakground for us to conduct irrigation canals useness for "lele sangkuriang" fish farming, using the recirculation system. The great benefit for all society of Pudak village, Muaro Kumpe district, muaro Jambi Regency can be expectifly reach.
\end{abstract}

Keywords: irrigation canals, lele sangkuriang fish, recirculation system

\begin{abstract}
Abstrak
Saluran irigasi lebih banyak dimanfaatkan untuk kegiatan pertanian, padahal justru potensi budidaya ikan sangat besar. Salah satu potensi tersebut adalah budidaya ikan lele sangkuriang. Ikan lele sangkuriang (C. gariepinus. Var. sangkuriang) termasuk ikan air tawar yang menyukai genangan air yang tidak tenang. Di sungai-sungai, ikan ini lebih banyak dijumpai di tempat-tempat yang aliran airnya tidak terlalu deras. Kondisi yang ideal bagi kehidupan lele sangkuriang adalah air yang mempunyai $\mathrm{pH}$ 6,5-9 dan bersuhu $24^{0}-$ $26^{\circ} \mathrm{C}$. Kandungan $\mathrm{O}_{2}$ yang terlalu tinggi akan menyebabkan timbulnya gelembunggelembung dalam jaringan tubuhnya. Sebaliknya penurunan kandungan $\mathrm{O}_{2}$ secara tiba-tiba, dapat menyebabkan kematiannya. Sistem resirkulasi merupakan salah satu cara untuk memperbaiki kualitas air, membantu distribusi oksigen ke segala arah, dan dapat menjaga akumulasi atau mengumpulnya hasil metabolisme beracun sehingga kadar atau daya racun dapat dikurangi dalam media pemeliharaan Untuk itulah maka kami membuat kegiatan pemanfaatan saluran irigasi untuk budidaya ikan lele sangkuring (C. gariepinus. Var. sangkuriang) menggunakan sistem resirkulasi dengan harapan kegiatan ini dapat memberikan manfaat kepada masyarakat Desa Pudak Kecamatan Muaro Kumpeh Kabupaten Muaro Jambi.
\end{abstract}

Kata kunci : saluran irigasi, ikan lele sangkuriang, sistem resirkulasi 
Jurnal Akuakultur Sungai dan Danau Vol. 2 No. 1 Tahun 2017 Hal. 1 - 8

ISSN Online 2503-4766

\section{PENDAHULUAN}

Pemeliharaan ikan lele sangkuring (C. gariepinus. Var. sangkuriang) pada fase larva merupakan tahapan yang paling kritis pada siklus hidupnya karena tingkat mortalitasnya paling tinggi, salah satu faktor penting dalam perawatan larva adalah pengelolaan kualitas air. Penurunan kualitas air atau kualitas air yang buruk dapat mengakibatkan ikan menjadi stres sehingga mudah terserang penyakit bahkan dapat menyebabkan kematian. Upaya yang dapat dilakukan terkait hal tersebut dengan menjaga kualitas air didalam media pemeliharaan larva ikan lele sangkuring (C. gariepinus. Var. sangkuriang).

Sistem resirkulasi merupakan salah satu cara untuk memperbaiki kualitas air, membantu distribusi oksigen ke segala arah, dan dapat menjaga akumulasi atau mengumpulnya hasil metabolisme beracun sehingga kadar atau daya racun dapat dikurangi dalam media pemeliharaan (Kelabora dan Sabariah, 2010).

Sistem resirkulasi merupakan pergerakan air dengan adanya air yang masuk dan keluar sehingga dapat menimbulkan arus dan pergerakan air. Pada perawatan larva, agar larva tidak terbawa arus dan tidak hanyut sebaiknya arus air dan pergerakan air tidak terlalu deras salah satu caranya dengan mengatur debit air yang masuk pada tempat perawatan larva, namun dalam hal ini belum diketahui pasti debit air yang optimal untuk perawatan larva ikan lele sangkuriang (Kelabora dan Sabariah, 2010)

Selama ini saluran irigasi lebih banyak dimanfaatkan untuk kegiatan pertanian, padahal justru potensi budidaya ikan sangat besar. Untuk itulah maka kami membuat kegiatan pemanfaatan sistem resirkulasi pada saluran irigasi untuk budidaya ikan lele sangkuring (C. gariepinus. Var. sangkuriang) dengan harapan kegiatan ini dapat memberikan manfaat kepada masyarakat Desa Pudak Kecamatan Muaro Kumpeh Kabupaten Muaro Jambi. Tujuan penelitian ini adalah mengetahui manfaat sistem resirkulasi pada saluran irigasi untuk budidaya Ikan Lele sangkuring (C. gariepinus. Var. sangkuriang)

\section{Metode Pelaksanaan}

Sebelum kegiatan pengabdian pada masyarakat dilakukan, terlebih dahulu koordinasi dengan Forum Layanan Ipteks Bagi Masyarakat (FlipMas) Kajanglako Jambi terkait strategi pengabdian kepada masyarakat, selain itu dilakukan juga penjaringan informasi terkait sistem budidaya ikan di Desa Pudak kondisi, permasalahan yang dihadapi, dan seberapa besar tingkat keberhasilan budidaya. Objek pengabdian mengambil para masyarakat tani dan pembudidaya ikan di Desa Pudak Kecamatan Muara Kumpeh Kabupaten Muaro Jambi karena masyarakat tersebut merupakan masyarakat binaan FlipMas Kajanglako Jambi yang secara rutin mengadakan layanan IPTEKS bagi masyarakat.

Bahasan yang disampaikan dalam kegiatan pengabdian pada masyarakat di Desa Pudak Kecamatan Muara Kumpeh Kabupaten Muaro Jambi adalah tentang Pemanfaatan Saluran Irigasi untuk Budidaya Ikan Lele Sangkuriang (Clarias gariepinus var sangkuriang) Di Desa Pudak Kecamatan Muara Kumpeh Kabupaten Muara Jambi.

Metode yang digunakan dalam kegiatan pengabdian ini adalah :

1. Metode Adragogi, yaitu setelah peserta dikumpulkan, materi disampaikan melalui ceramah dengan materi yang telah disiapkan 
Jurnal Akuakultur Sungai dan Danau Vol. 2 No. 1 Tahun 2017 Hal. 1 - 8

ISSN Online 2503-4766

2. Mengadakan diskusi, tanya jawab atau bertukar pengalaman dalam memecahkan suatu masalah.

\section{HASIL DAN PEMBAHASAN}

Hasil yang didapatkan dari kegiatan ini meliputi parameter kinerja produksi antara lain derajat kelangsungan hidup (SR), laju pertumbuhan bobot harian (SGR), konversi pakan (FCR), koefesien keragaman (KK), parameter kualitas air, dan analisis ekonomi.

\section{Kinerja Produksi}

Kinerja produksi Ikan Lele Sangkuriang (Clarias gariepinus var sangkuriang) yang dipeliharan oleh pembudidaya di daerah penelitian pada daerah rawa menunjukkan hasil yang baik untuk kategori budidaya pembesaran ikan, nilai derajat kelangsungan hidup, laju pertumbuhan spesifik, konversi pakan, dan koefisien keragaman masing-masing sebesar 93,78\% ; 7,75\%; 1,03; dan 0.02 (Tabel 1). Hasil kegiatan secara lengkap disajikan pada tabel dibawah ini.

Tabel 1. Data parameter kinerja produksi Ikan Lele Sangkuriang (Clarias gariepinus var sangkuriang) di Desa Pudak Muaro kumpeh Jambi selama 90 hari masa pemeliharaan

\begin{tabular}{clc}
\hline No & \multicolumn{1}{c}{ Parameter Produksi } & Nilai \\
\hline 1. & Derajat kelangsungan hidup $(\%)$ & 93.78 \\
2. & Laju pertumbuhan spesifik (\%/hari) & 7.75 \\
3. & Konversi pakan & 1.03 \\
4. & Koefisien keragaman $(\%)$ & 0.02 \\
\hline
\end{tabular}

Derajat kelangsungan hidup adalah persentase perbandingan jumlah ikan yang hidup hingga akhir pemeliharaan dengan jumlah ikan pada awal pemeliharaan. Dari kegiatan ini diperoleh derajat kelangsungan hidup pada akhir masa pemeliharaan sebesar 93,78\% (Tabel 3). Derajat kelangsungan hidup (SR) merupakan parameter utama dalam produksi biota akuakultur yang dapat menunjukkan keberhasilan produksi tersebut. Jika diperoleh nilai SR yang tinggi pada suatu kegiatan budidaya, maka dapat dikatakan bahwa kegiatan budidaya yang dilakukan telah berhasil. Pemeliharaan ikan lele sangkuriang oleh pembudidaya di lokasi kegiatan menunjukkan hasil yang baik, dengan nilai kelangsungan hidup yang tinggi. Jika dilihat dari padat tebar yang di berikan, padat tebar ikan yang digunakan cukup tinggi untuk skala pembesaran yakni $250 \mathrm{ekor} / \mathrm{m}^{2}$. Hal ini menunjukkan bahwa padat tebar ikan yang tinggi tidak memberikan efek stres terhadap ikan lele sangkuriang, hal ini berbeda dengan pendapat Hepher dan Pruginin (1981) yang menyatakan bahwa padat tebar ikan yang tinggi dapat mempengaruhi lingkungan budidaya dan interaksi ikan. Penyakit dan kekurangan oksigen akan mengurangi jumlah ikan secara drastis, terutama ikan yang berukuran kecil.

Selain itu tingginya kelangsungan hidup diduga disebabkan oleh kualitas air yang baik dan cenderung stabil selama masa pemeliharaan, kandungan oksigen berada diatas 3 $\mathrm{mg} / \mathrm{l}$ suhu berkisar antara $27-32{ }^{0} \mathrm{C}$ dan $\mathrm{pH}$ 6-8 (Tabel 4.) Kualitas air yang terus dijaga dengan baik melalui pergantian air, serta pemberian pakan yang mencukupi untuk ikan. Pengelolaan air yang baik menyebabkan tingkat kelangsungan hidup ikan tinggi. Kematian ikan terjadi pada fase awal pemeliharaan pada saat ikan berukuran kecil. 
Jurnal Akuakultur Sungai dan Danau Vol. 2 No. 1 Tahun 2017 Hal. 1 - 8

ISSN Online 2503-4766

Laju pertumbuhan spesifik (SGR) yang dihasilkan selama pemeliharaan sebesar 7,75\% per hari (Tabel 1) dan cenderung mengalami peningkatan selama masa pemeliharaan (Gambar 1). Pertumbuhan ikan yang relatif tinggi diduga disebabkan karena nafsu makan ikan yang tinggi, sehingga energi yang dihasilkan digunakan untuk meningkatkan berat atau bobot tubuh ikan. Hal ini sesuai dengan pendapat Zonneveld, et al (1991) pertumbuhan terjadi karena terdapat kelebihan energi yang berasal dari pakan setelah dikurangi dengan energi untuk metabolisme dan energi yang terkandung di dalam feses. Selain itu stabilitas kualitas air diduga memberikan pengaruh dalam menekan tingkat stress pada ikan sehingga pertumbuhan tidak terganggu. Pertumbuhan selalu dikaitkan dengan jumlah pakan yang diberikan dan kualitas air dalam wadah pemeliharaan, karena suhu air dan kadar oksigen dalam air mempengaruhi nafsu makan, proses metabolisme dan pertumbuhan (Goddard 1996).

Menurut NCR (1993) konversi pakan merupakan perbandingan antara jumlah bobot pakan dalam keadaan kering yang diberikan selama kegiatan budidaya yang dilakukan dengan bobot total ikan pada akhir pemeliharaan dikurangi dengan jumlah bobot ikan mati dan bobot awal ikan selama pemeliharaan. Pada Tabel 3 terlihat bahwa nilai FCR pemeliharaan ikan lele sangkuriang sebesar 1,03. Nilai ini berarti bahwa untuk menghasilkan $1 \mathrm{~kg}$ daging ikan dibutuhkan 1,03 kg pakan. Menurut Effendi (2004), Semakin besar nilai FCR, maka semakin semakin banyak pakan yang dibutuhkan untuk memproduksi $1 \mathrm{~kg}$ ikan daging kultur. FCR seringkali dijadikan indikator kinerja teknis dalam mengevaluasi suatu usaha akuakultur.

Koefisien keragaman (KK) bobot menggambarkan tingkat keragaman bobot ikan pada akhir pemeliharaan, yaitu semakin tinggi nilai koefisien keragaman maka tingkat keseragaman bobot semakin kecil. Variasi ukuran pada umumnya disebabkan oleh persaingan ukuran antar ikan, baik jumlah maupun distribusinya. Hal ini selanjutnya dapat menimbulkan dominasi dalam mendapatkan pakan, sehingga ikan yang besar akan semakin mudah mendapatkan pakan dan lebih cepat tumbuh dibandingkan dengan ikan yang relatif lebih kecil. Koefisien keragaman bobot lele sangkuriang yang dipelihara selama 90 hari menunjukkan nilai KK sebesar 0,02 \%, nilai ini menunjukkan bahwa tingkat keseragaman ikan lele angkuriang saat panen sangat tinggi, hal ini diduga keseragaman bobot pada awal pemeliharaan dan peluang mendapatkan makanan yang merata menyebabkan tidak terjadi kesenjangan ukuran bobot pada akhir masa pemeliharaan.

Perkembangan Bobot Rata-Rata (g)

Berdasarkan Gambar 2 terlihat bahwa perkembangan bobot rata-rata pada setiap perlakuan selama 90 hari pemeliharaan menunjukkan tingkat pertumbuhan yang positif hal ini ditandai dengan pola grafik yang meningkat secara linier, yaitu bobot rata-rata semakin lama masa pemeliharaan semakin meningkat. Pada akhir pemeliharaan bobot rata-rata ikan lele sangkuriang selama empat kali periode sampling masing-masing sebesar 0,0150 gr, 60,067 gr, 101,233 gr dan 124,567 gr. 
Jurnal Akuakultur Sungai dan Danau Vol. 2 No. 1 Tahun 2017 Hal. 1 - 8

ISSN Online 2503-4766

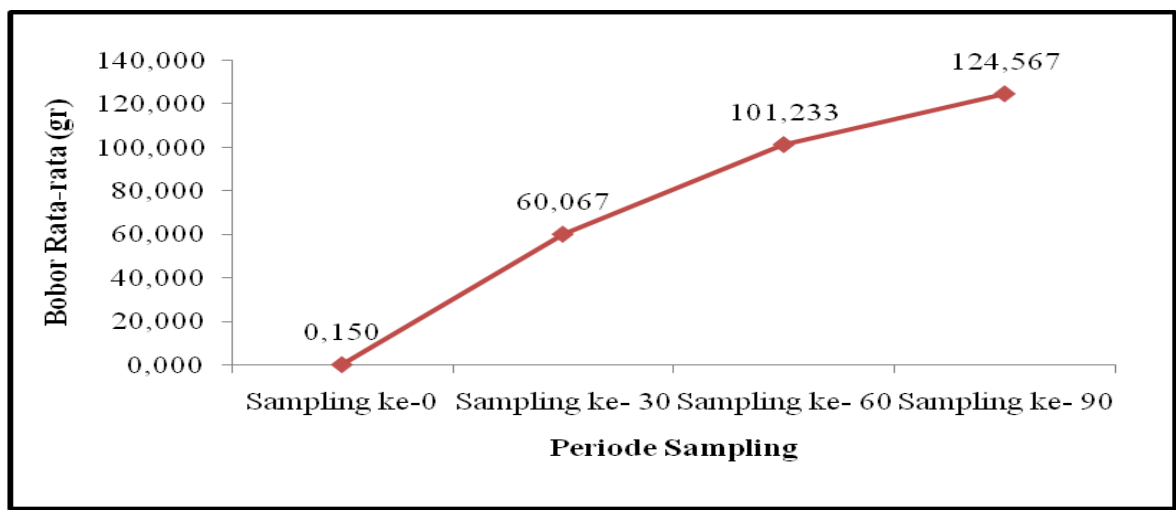

Gambar 1. Perkembangan bobot rata-rata Ikan Lele Sangkuriang (Clarias gariepinus var sangkuriang) di Desa Pudak Muaro kumpeh Jambi selama 90 hari masa pemeliharaan

\section{Kualitas Air}

Parameter kualitas air yang diukur dalam kegiatan ini meliputi suhu, $\mathrm{pH}$, DO, amonia, nitrit, dan alkalinitas (Tabel 2). Data kualitas air yang didapatkan berada pada kisaran yang sesuai dengan kriteria pemeliharaan ikan lele sangkuriang. Hal ini menunjukkan bahwa parameter kualitas air yang diukur termasuk pada kategori layak untuk pemeliharaan ikan lele sangkuriang.

Tabel 2. Kisaran kualitas air (suhu, pH dan DO) Ikan Lele Sangkuriang (Clarias gariepinus var sangkuriang) di Desa Pudak Muaro kumpeh Jambi selama 90 hari masa pemeliharaan

\begin{tabular}{lccccc}
\hline \multirow{2}{*}{ Parameter } & \multicolumn{2}{c}{ Awal } & \multicolumn{2}{c}{ Akhir } & \multirow{2}{*}{ Kisaran Optimal } \\
& Pagi & Sore & Pagi & Sore & \\
\hline Suhu $\left({ }^{\circ} \mathrm{C}\right)$ & 27 & 30 & 28 & 31 & $25-32^{\circ} \mathrm{C}$ (Mulyanto 1992) \\
pH & 5.7 & 6 & 6.7 & 6.5 & $6,5-8$ (Khairuman 2008) \\
DO $(\mathrm{mg} / \mathrm{L})$ & 3.2 & 3.5 & 3.0 & 3.6 & $>3 \mathrm{mg} / \mathrm{l}$ (Khairuman 2008) \\
\hline
\end{tabular}

\section{Analisis usaha}

Analisis usaha pada Tabel 3 menunjukkan gambaran analisis secara ekonomi pada pemeliharaan ikan lele sangkuriang di lokasi kegiatan. Analisis ini di hitung berdasarkan data kinerja produksi serta harga terkini sarana dan prasarana pembesaran ikan lele sangkuriang. Berikut disajikan data produksi ikan lele sangkuriang di lokasi.

Tabel 3. Data produksi Ikan Lele Sangkuriang (Clarias gariepinus var sangkuriang) di Desa Pudak Muaro kumpeh Jambi selama 90 hari masa pemeliharaan

\begin{tabular}{clr}
\hline No & \multicolumn{1}{c}{ Kinerja Produksi } & Nilai/hasil \\
\hline 1 & Luasan (m2) & 6 \\
2 & Jumlah benih tebar awal (ekor) & 15000 \\
3 & Padat tebar (ekor/m2) & 2500 \\
\hline \hline
\end{tabular}


Jurnal Akuakultur Sungai dan Danau Vol. 2 No. 1 Tahun 2017 Hal. 1 - 8

ISSN Online 2503-4766

\begin{tabular}{clr}
\hline \hline 4 & Lama pemeliharaan (hari) & 90 \\
5 & Jumlah panen (ekor) & 14067 \\
11 & Bobot awal (g/ekor) & 0.150 \\
12 & Bobot akhir (g/ekor) & 124.57 \\
13 & Biomasa awal (g) & 2250 \\
14 & Biomasa akhir (g) & $1,752,279$ \\
15 & Biomasa akhir (kg) & 1,752 \\
16 & Harga Jual (Rp) & 16000 \\
\hline
\end{tabular}

Data produksi dari kegiatan pembesaran ikan lele sangkuriang di lokasi kegiatan menunjukkan bahwa lama pemeliharaan ikan lele sangkuriang selama 90 hari. Kepadatan tebar sebesar 250 ekor $/ \mathrm{m}^{2}$. Harga jual ikan lele sangkuriang sebesar Rp. 16.000 dengan total biomassa panen sebesar $1.752 \mathrm{~kg}$.

Dari data tersebut dihitung analisis usaha pembesaran ikan lele sangkuriang di lokasi kegiatan dalam satu siklus produksi. Hasil perhitungan analisis usaha disajikan pada tabel dibawah ini.

Tabel 4. Analisis usaha Ikan Lele Sangkuriang (Clarias gariepinus var sangkuriang) di Desa Pudak Muaro Kumpeh Jambi selama 90 hari masa pemeliharaan

\begin{tabular}{clc}
\hline No & \multicolumn{1}{c}{ Uraian } & Jumlah \\
\hline 1 & Biaya tetap (Rp) & 1519466.667 \\
2 & Biaya variabel (Rp) & 17704466.67 \\
3 & Biaya total (Rp) & 19223933.33 \\
4 & Penerimaan (Rp) & $28,042,432$ \\
5 & Keuntungan (Rp) & $8,818,499$ \\
6 & R/C ratio & 1.46 \\
7 & BEP (Rp) & 4121656.371 \\
8 & BEP Unit (kg) & 94.97 \\
9 & HPP & 10968 \\
\hline
\end{tabular}

Pada kegiatan ini diketahui bahwa nilai R/C sebesar 1,46 yang artinya bahwa setiap Rp 1,00 biaya yang dikeluarkan pada usaha pembesaran ikan lele sangkuriang ini akan menghasilkan penerimaan sebesar 1,46 (Tabel 4). Nilai R/C lebih dari satu menunjukkan bahwa usaha ini layak untuk dijalankan.

Break even point (BEP) pada usaha pembesaran ikan lele sangkuriang di Desa Pudak ini sebesar Rp 4.121.656,371 (Tabel 6), artinya pada kondisi tersebut pembudidaya tidak akan mengalami keuntungan ataupun kerugian. Untuk nilai BEP berdasarkan volume penjualan dalam bentuk ekor diperoleh nilai BEP sebesar $94.97 \mathrm{~kg} / \mathrm{karamba}$, artinya nilai tersebut menunjukkan apabila penjualan benih hanya memperoleh $94.97 \mathrm{~kg}$ maka usaha tidak mengalami keuntungan ataupun kerugian. Harga Pokok Produksi (HPP) merupakan nilai atau biaya yang dikeluarkan untuk memproduksi 1 unit produk (Rahardi et al., 1998). 
Jurnal Akuakultur Sungai dan Danau Vol. 2 No. 1 Tahun 2017 Hal. 1 - 8

ISSN Online 2503-4766

HPP diperoleh dari perbandingan antara biaya total dengan jumlah produksi. Harga pokok penjualan (Tabel 6) yaitu Rp 10,968/kg. HPP harus lebih rendah dari harga jual agar dapat memperoleh keuntungan. Secara umum nilai HPP pada pemeliharann ikan lele sangkuriang di Desa Pudak masih berada dibawah harga jual, sehingga usaha ini tadak akan mengalami kerugian.

\section{KESIMPULAN}

Kinerja produksi ikan lele sangkuriang di Desa Pudak Kecamatan Muaro Kumpeh Kabupaten Muara Jambi menunjukkan hasil yang baik sebagai indikator keberhasilan budidaya ikan, hal ini ditunjukkan dengan nilai derajat kelangsungan hidup, laju pertumbuhan spesifik, konversi pakan, dan koefisien keragaman masing-masing sebesar $93,78 \% ; 7,75 \% ; 1,03 ;$ dan 0.02 .

Jika dilihat dari analisis usaha, kegiatan usaha pembesaran ikan lele sangkuriang di Desa Pudak Kecamatan Muaro Kumpeh Kabupaten Muara Jambi tergolong layak, hal ini terlihat dari nilai R/C sebesar 1,46. Nilai R/C lebih dari satu menunjukkan bahwa usaha ini layak untuk dijalankan.

Perlu dilakukan kajian lainnya terkait dengan analisis penggunaan faktor produksi di lokasi kegiatan dan analisis kesesuaian lahan demi meningkatkan hasil produksi ikan lele sangkuriang.

\section{Ucapan Terima Kasih}

Ucapan terima kasih disampaikan kepada Forum Layanan Ipteks Bagi Masyarakat (FlipMas) Kajanglako Jambi, aparat dan masyarakat Desa Pudak Kecamatan Muara Kumpeh Kabupaten Muaro Jambi sehingga kegiatan pengabdian ini dapat terlaksana dengan baik.

\section{REFERENSI}

Barus,T.A. 2002. Pengantar Limnologi. Universitas Sumatera Utara. Medan.

Boyd CE. 1990. Water Quality in Pond for Aquaculture. Auburn University, Alabama (US): Auburn University Agriculture Experiment Station.

Cahyono, B. 2009. Budidaya lele dan Betutu (ikan langka bernilai tinggi). Pustaka Mina. Jakarta.

Dinas Pertanian Tanaman Pangan Provinsi Jambi. 2015. Buku Data Pertanian Provinsi Jambi 2014-2015. Dinas Pertanian Tanaman Pangan Provinsi Provinsi Jambi.

Direktorat Jenderal Perikanan Budidaya. 2015. Laporan Kinerja (LKj) Triwulan I. Jakarta: DJPB

Effendi I. 2004. Pengantar Akuakultur. Jakarta (ID): Penebar Swadaya.

Goddard S. 1996. Feed Management in Intensive Aquaculture. New York (US): Chapman and Hall.

Hendriyanto. 2010. Optimalisasi penggunaan input dan analisis finansial pada usaha pembesaran udang windu Penaeus monodon di Desa Lamaran Tarung Kecamatan Cantigi Kabupaten Indramayu [skripsi]. Bogor (ID): Institut Pertanian Bogor.

Huisman EA, Boon JH, Zonneveld N. 1991. Prinsip-prinsip budidaya ikan. Jakarta (ID): PT. Gramedia Pustaka Utama. 
Jurnal Akuakultur Sungai dan Danau Vol. 2 No. 1 Tahun 2017 Hal. 1 - 8

ISSN Online 2503-4766

Jamaludin .2015. Analisis Pendapatan Usaha Pembesaran Ikan Lele Sangkuriang (Clarias Gariepinus) Di Bojong Farm Kabupaten Bogor. [Skripsi]. Program Studi Agribisnis Fakultas Sains Dan Teknologi Universitas Islam Negeri Syarif Hidayatullah. Jakarta

Lukito AM. Lele Ikan Berkumis Paling Populer. Jakarta: Agromedia, 2002

Madinawati. N.S dan Yoel. 2011. Pemberian pakan yang berbeda terhadap pertumbuhan dan kelangsungan hidup benih ikan lele dumbo (Clarias gariepinus). Media Litbang Sulteng

Mahyuddin, K. 2008. Paduan Lengkap Agribisnis Lele. Depok : Penebar Swadaya.

Nurmalina R, Sarianti T, Karyadi A. 2010. Studi Kelayakan Bisnis. Bogor (ID): Butt Design \& Printing.

[NRC] National Research Council. 1993. Nutrient Requirement of Fish. Washington DC: National Academic of Science Press.

Rosiah, E. 2005. Analisis kelayakan finansial usaha pembenihan ikan mas di Desa Sumurgintung, Kecamatan Pagaden, Kabupaten Subang, Provinsi Jawa Barat [skripsi]. Bogor (ID): Institut Pertanian Bogor.

Sudana, S.N., Arga, I.W., Suparta, N. 2013. Kelayakan Usaha Budidaya Ikan Lele Dumbo (Clarias gariepinus) dan Pengaruhnya Terhadap Tingkat Pendapatan Petani Ikan Lele di Kabupaten Tabanan. J. Manajemen Agribisnis. 1(1)

Steel GD, Torrie JH. 1981. Prinsip-prinsip dan Prosedur Statistika. Terjemahan Jakarta (ID): PT. Gramedia Pustaka Utama. 747 Hlm.

Zonneveld. N, E. A. Huisman, J. H. Boon. (1991). Prinsip-prinsip budidaya ikan. Gramedia 